\title{
Preparation and Evaluation of Polyherbal Vanishing Cream of Ethanolic Extract of Crude Drugs
}

\author{
Mohd Fahad Uddin*, Mohd Kaleem Ullah, Mohd Aijaz Ahmed, Sana Samreen, Hafsa Habeeb \\ Department of Pharmaceutics, Shadan College of Pharmacy, Hyderabad, Telangana.
}

\begin{abstract}
In the present study, polyherbal oil-in-water vanishing emulsion cream was formulated based on the antifungal, anti-microbial, anti-inflammatory, skin-soothing, and anti-aging potential of aloe vera, kachora plant, linseed, long pepper, nagarmotha plant, nutmeg, turmeric, and wheat grain. All herbs were extracted by using the maceration method with ethanol as solvent. The prepared vanishing cream was then evaluated for various parameters, and results were obtained within acceptable values. The prepared vanishing cream was found stable \& firm during the stability studies performed as per the guidelines of International Council for Harmonisation (ICH) at different temperatures for a period of a month. Results have shown that formulations have good stability. It can be concluded that the prepared polyherbal vanishing cream was pleasing, simply washable without side effects, and can be utilized to protect and avoid degradation of the skin.
\end{abstract}

Keywords: Crude drugs, Emulsion, Ethanolic extract, Polyherbal, Stability, Vanishing cream.

\section{INTRODUCTION}

A cream is a semisolid formulation comprising more than $20 \%$ of water and $50 \%$ of lipid vehicles usually to apply on skin. A drug molecule is also incorporated by dissolving or dispersing it in a suitable cream base (Osborne, 2008). Various sorts of creams are accessible in the market to protect the consistency of the skin. Many irritable and unpleasant substances sticking on the skin includes skin secretions, sweat, salts, sebum as well as deposits of dirt bounded by oily substances require a special process of expulsion. Hence, a vanishing cream is eminent in protecting the skin from the above substances (Akhtar et al., 2011).

Most of the existing vanishing creams manufactured from synthetic sources offer fairness, yet they have few side effects, for example, tingling or unfavorably allergic responses. Perhaps, creams prepared from natural and herbal sources are devoid of any above side effects.

Herbalism has become a center of research and focus in pharmaceutical formulation and drug discovery due to the advancements in analysis and quality along with enhanced clinical research in treating and preventing disease (Faisal, 2019). According to the World Health Organization (WHO), more than $80 \%$ of people world- wide depend upon the herbal medicines and about 25\% of modern drugs have been derived from plants in the USA (Steven, 2015). In India, the Ayurvedic system of medicine was derived from the inscriptions from 1500 BC. Several herbs and minerals utilized in the Ayurvedic system of medicine during the 1st millennium BC were explained by famous herbalists such as Charaka and Sushruta (Dwivedi and Dwivedi, 2007).

Vanishing cream is so termed due to their no presence or zero evidence of presence upon application and rubbing on the surface of the skin. It forms a thin imperceptible and invisible film on the skin, followed by the dissipation of water that gives non-glossy appearance (Saraf and Saraf, 2019). These creams are generally o/w type emulsion consisting of stearic acid, an alkali (form soap), a polyol (skin softening agent), and water. Hazeline Snow was the first marketed vanishing cream in 1892 by Burroughs Welcome (Ugandar and Deivi, 2013). Glycerine is a non-toxic polyol compound widely used in giving smoothness and lubrication to pharmaceutical preparations. Stearic acid is a fatty acid (saturated) utilized in the manufacture of detergents, soaps, and cosmetics. Potassium hydroxide is an inorganic compound used to prepare the corresponding potassium soaps. Methylparaben used as a preservative and anti-fungal agent

\section{Corresponding author}

Sayma Khader

Email : sayma.maryam95@gmail.com 

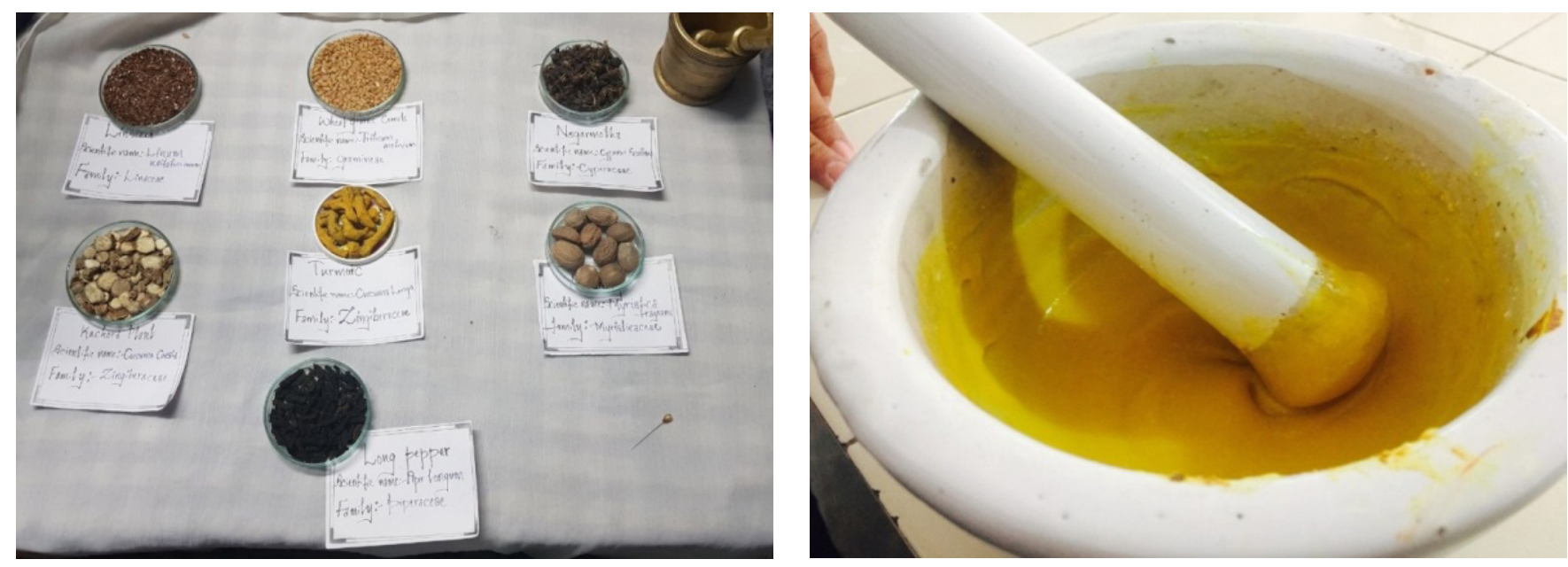

Fig. 1: Crude Drugs \& Prepared Polyherbal Vanishing Cream

in various cosmetics and personal care products (Datta and Paramesh, 2010).

The present research work was done to formulate and evaluate the ethanolic extract of polyherbal (aloe vera, kachora plant, linseed, long pepper, nagarmotha plant, nutmeg, turmeric, wheat grain) vanishing cream.

\section{MATERIALS AND METHODS}

\subsection{Materials Used}

The crude drugs utilized in the preparation of polyherbal vanishing cream are listed in Table 1 . They were obtained

Table 1: Crude drugs used in polyherbal formulation

\begin{tabular}{|c|c|c|c|c|c|c|}
\hline $\begin{array}{l}\text { Common } \\
\text { name }\end{array}$ & $\begin{array}{l}\text { Biological } \\
\text { source }\end{array}$ & Family & $\begin{array}{l}\text { Part } \\
\text { used }\end{array}$ & $\begin{array}{l}\text { Chemical } \\
\text { constituents }\end{array}$ & $\begin{array}{l}\text { Primary } \\
\text { use }\end{array}$ & Other uses \\
\hline Aloe & Aloe vera & $\begin{array}{l}\text { Xanthorr- } \\
\text { hoeaceae }\end{array}$ & Leaves & $\begin{array}{l}\text { Acetylated mannans, } \\
\text { Anthraquinone, } \\
\text { Anthrones, } \\
\text { Emodin, Lectins, } \\
\text { Protein, Calcium, } \\
\text { Magnesium, Zinc, } \\
\text { Vitamins A, E \& C }\end{array}$ & Anti-aging & $\begin{array}{l}\text { Burns, eczema immune } \\
\text { system, hayfever, } \\
\text { maintain the tone of } \\
\text { blood vessels, } \\
\text { rejuvenate old tissues, } \\
\text { support healthy skin }\end{array}$ \\
\hline $\begin{array}{l}\text { Kachora } \\
\text { Plant }\end{array}$ & $\begin{array}{l}\text { Curcuma } \\
\text { caesia }\end{array}$ & Zinziberaceae & Rhizome & $\begin{array}{l}\text { Camphor, Turmerone } \\
\text { Curcumene, } \\
\text { 1,8-Cineole, } \\
\text { Elemene, Borneol, } \\
\text { Curcumene, } \\
\text { Terpenoids, } \\
\text { Flavonoids, Steroids }\end{array}$ & Rubifacient & $\begin{array}{l}\text { Aromatic, anthelmintic, } \\
\text { antipyretic, alexiteric, } \\
\text { leucoderma, bronchitis, } \\
\text { tumors, skin diseases, } \\
\text { sprains, bruises, } \\
\text { dermatitis, ulcer, and } \\
\text { wounds }\end{array}$ \\
\hline Linseed & $\begin{array}{l}\text { Linum } \\
\text { usitatissimum }\end{array}$ & Liliaceae & Seeds & $\begin{array}{l}\text { Acyanogenetic } \\
\text { glycosides } \\
\text { (linamarin), fixed oil, } \\
\text { mucilage, enzyme } \\
\text { (linase) }\end{array}$ & $\begin{array}{l}\text { Fatty } \\
\text { material }\end{array}$ & $\begin{array}{l}\text { Liniments, lotions, } \\
\text { curing scabies, } \\
\text { skin disease, in } \\
\text { manufacturer of soap, } \\
\text { grease, polymer, } \\
\text { plasticizer, polish and } \\
\text { linoleum }\end{array}$ \\
\hline Long pepper & Piper longum & Piperaceae & $\begin{array}{l}\text { Dried } \\
\text { fruiting } \\
\text { spikes }\end{array}$ & $\begin{array}{l}\text { Alkaloids piperine, } \\
\text { piplartine and } \\
\text { piplasterol, essential } \\
\text { oil, pungent resin }\end{array}$ & Antioxidant & $\begin{array}{l}\text { Diseases of respiratory } \\
\text { tract } \& \text { spleen, } \\
\text { bronchitis, tumors }\end{array}$ \\
\hline $\begin{array}{l}\text { Nagarmotha } \\
\text { Plant }\end{array}$ & $\begin{array}{l}\text { Cyperus } \\
\text { scariosus }\end{array}$ & Cyperaceae & Tuber & $\begin{array}{l}\text { Cypriol, cyperene, } \\
\text { a-copaene, } \\
\text { caryophyllene oxide }\end{array}$ & Antioxidant & $\begin{array}{l}\text { Nausea, fever, } \\
\text { inflammation, pain } \\
\text { reduction, muscle } \\
\text { relaxation, soap making }\end{array}$ \\
\hline Nutmeg & $\begin{array}{l}\text { Myristica } \\
\text { fragrance }\end{array}$ & Myristicaceae & $\begin{array}{l}\text { Dried } \\
\text { kernels } \\
\text { of the } \\
\text { seeds }\end{array}$ & $\begin{array}{l}\text { Volatile oil, fat } \\
\text { Myristicin, elimicin, } \\
\text { safrole, palmitic acid, } \\
\text { oleic acid, lauric acid }\end{array}$ & Antioxidant & $\begin{array}{l}\text { Aromatic, stimulant, } \\
\text { carminative }\end{array}$ \\
\hline
\end{tabular}


Cont...

\begin{tabular}{|c|c|c|c|c|c|c|c|}
\hline Turmeric & $\begin{array}{l}\text { Curcuma } \\
\text { longa }\end{array}$ & Zinziberaceae & Rhizome & \multirow{2}{*}{\multicolumn{2}{|c|}{$\begin{array}{l}\text { Curcuminoids, } \\
\text { curcumin, volatile oil, } \\
\text { fixed oil and acids, } \\
\text { cineole, borneol, } \\
\text { sabinene } \\
\text { Starch }\end{array}$}} & $\begin{array}{l}\text { Anti- } \\
\text { bacterial }\end{array}$ & $\begin{array}{l}\text { Anti-inflammatory, anti- } \\
\text { microbial, stimulant, } \\
\text { pains and bruises, in } \\
\text { cosmetics }\end{array}$ \\
\hline Wheat Grain & $\begin{array}{l}\text { Triticum } \\
\text { aestivum }\end{array}$ & Gramineae & $\begin{array}{l}\text { Fully } \\
\text { grown } \\
\text { grains }\end{array}$ & & & Nutrients & $\begin{array}{l}\text { Absorbent, demulcent, } \\
\text { disintegrating agent, } \\
\text { Binder, lubricant, } \\
\text { diluents }\end{array}$ \\
\hline \multicolumn{4}{|c|}{ Table 2: Ingredients of vanishing cream formulation } & \multicolumn{4}{|c|}{ Table 3: Evaluation of Vanishing Cream Formulation } \\
\hline \multicolumn{2}{|l|}{ Ingredient } & \multicolumn{2}{|c|}{ Quantity (\%) } & S. No. & \multicolumn{2}{|c|}{ Parameter } & Observation \\
\hline \multicolumn{2}{|c|}{ Polyherbal extract } & \multicolumn{2}{|l|}{4.5} & 1. & \multicolumn{2}{|l|}{ Color } & Pale Yellow \\
\hline Stearic acid & & \multicolumn{2}{|l|}{17} & 2. & \multicolumn{2}{|l|}{ Odor } & Characteristic \\
\hline Glycerine & & \multicolumn{2}{|l|}{6} & & \multicolumn{2}{|c|}{ Appearance } & \\
\hline \multicolumn{2}{|c|}{ Potassium hydroxide } & \multicolumn{2}{|l|}{0.5} & 3. & \multicolumn{2}{|c|}{ By visual } & Homogeneous \\
\hline \multicolumn{2}{|c|}{ Sodium carbonate } & \multicolumn{2}{|l|}{0.5} & & \multicolumn{2}{|c|}{ By Touch } & Smooth and Consistent \\
\hline Water & & \multicolumn{2}{|l|}{71} & 4. & \multicolumn{2}{|c|}{ Viscosity } & $1100-1800 \mathrm{cp}$ \\
\hline Perfume & & \multicolumn{2}{|l|}{0.5} & 5. & \multicolumn{2}{|l|}{$\mathrm{pH}$} & $5.8-6.10$ \\
\hline \multirow{3}{*}{\multicolumn{4}{|c|}{$\begin{array}{l}\text { from the local sources. They were crushed, powdered, } \\
\text { and sieved to get a uniform powdered mixture. Other } \\
\text { excipients used are stearic acid, glycerine, potassium } \\
\text { hydroxide, and methylparaben obtained from respec- } \\
\text { tive suppliers. The formulation of the vanishing cream }\end{array}$}} & 6. & \multicolumn{2}{|c|}{ Spreadability } & 13.7 (Good) \\
\hline & & & & 7. & \multicolumn{2}{|c|}{ Irritation test } & $\begin{array}{l}\text { No irritation, } \\
\text { No redness, } \\
\text { No edema }\end{array}$ \\
\hline & & & & 8. & \multicolumn{2}{|c|}{$\begin{array}{l}\text { Type of emulsion } \\
\text { (Dilution test) }\end{array}$} & O/W type \\
\hline
\end{tabular}
is given in Fig. 1 and Table 2.

\subsection{Method of Preparation}

\subsubsection{Preparation of Alcoholic Extract of Crude Drugs}

Each powdered crude drug, weighing 5 gm was taken into a conical flask; $100 \mathrm{~mL}$ of ethanol was added to it and sealed with aluminum foil. The mixture was subjected to maceration for 5 days. After 5 days, the above mixture was filtered and the filtrate was concentrated at $60^{\circ} \mathrm{C}$ for an hour and kept in a tight container.

\subsubsection{Preparation of Vanishing Creams}

Preparation of vanishing cream involves three steps,

Preparation of Oil Phase: $17 \%$ stearic acid, $0.5 \%$ potassium hydroxide, and $0.5 \%$ sodium carbonate was mixed thoroughly into porcelain dish vigorously by melting at $70^{\circ} \mathrm{C}$.

Preparation of Aqueous Phase: $4.5 \%$ of ethanolic extract of crude drugs, $6 \%$ glycerine and $71 \%$ of water were taken into another porcelain dish and heated at $70^{\circ} \mathrm{C}$.

Addition of Aqueous Phase to Oil Phase: The aqueous phase was mixed with the oil phase with constant stirring at $70{ }^{\circ} \mathrm{C}$. Once the transfer was done, it was cooled down to room temperature followed by the addition of $0.5 \%$ perfume. The final product was then transferred to a suitable air-tight container.

\subsection{Evaluation of Polyherbal Vanishing Cream}

Vanishing creams after formulation, may experience physical and chemical changes that may alter their stability. Therefore, the vanishing creams ought to be assessed for their stability before dispensing to ensure their stability all through their shelf-life. Evaluation of vanishing creams can be done by the following tests.

\subsubsection{Organoleptic Evaluation}

The properties of formulation used in the polyherbal vanishing cream were deliberated by quality, visual appearance, and characteristics. The cream was observed for color, odor, and appearance. The results are listed in Table 3.

\subsubsection{Presence of Unwanted Substances}

A small quantity of cream was spread on a grease-free glass slide and observed against diffused light to make sure the presence of foreign particles.

\subsubsection{Strength of $p H$}

The cream was weighed accurately $5 \pm 0.01 \mathrm{~g}$ and dispersed with $45 \mathrm{ml}$ of water taken in a $100 \mathrm{ml}$ beaker. The $\mathrm{pH}$ of the formulation was determined using a digital $\mathrm{pH}$ meter at $27^{\circ} \mathrm{C}$ temperature (Matangi et al., 2014). 


\subsubsection{Cream Viscosity}

The viscosity of the prepared o/w vanishing cream was measured by Brookfield Viscometer (LVT DV-E) with spindle CP-52 at different speeds and shear rates. The measurements were calculated within the range of $0.10,0.20,0.30,0.40$ and $0.50 \mathrm{rpm}$ speed velocity with $60 \mathrm{sec}$ between two successive speeds as equilibration. The shear rate ranging from $0.20-1.0$ sec- 1 was applied at room temperature (Indian Standard, 1978; Brookfield).

\subsubsection{Cream Spreadability Studies}

Spreadability is an important criterion for semisolids dosage forms as the therapeutic effectiveness of these formulations depends on their spreading value. It is defined as the area on the skin to which on the application of the cream is ready spreads. Spreadability is expressed in terms of seconds. It is performed by taking the cream in between two slides to slip off from each other, under the influence of a definite load. A good cream formulation will take less time for the separation.

Two glass slides of standard dimensions were taken, and a small amount of prepared cream was placed on one of the slides. The other slide was sandwiched between the two slides by inserting it on the top of the formulation across the length of $5 \mathrm{~cm}$ along with the slide. A weight of $100 \mathrm{~g}$ was exerted on the upper slide so that the prepared cream was pressed consistently to form a thin layer. The weight was then removed, and the remaining cream remained to attach to the slides were eradicated. One of slides was fixed on which the cream was placed, and subsequent portable slide was placed over it, with one end attached to a string to which burden could be applied by the assistance of a straightforward pulley and a pan. A $30 \mathrm{~g}$ weight was put on the pan and the time taken for the upper slide to venture to travel the distance of $5 \mathrm{~cm}$ and separate away from the lower slide under the direction of the weight was noted (Das et al., 2012). The spreadability was determined by using the formula as follows:

$$
\text { Spreadability }(S)=\frac{M \times L}{T}
$$

Where, $\quad \mathrm{M}=$ weight $(\mathrm{gm})$ tied to upper glass slide

$$
\mathrm{L}=\text { length }(\mathrm{cm}) \text { moved on a glass slide }
$$

$$
\mathrm{T}=\text { time taken }(\mathrm{sec})
$$

The results are shown in Table 3.

\subsubsection{Skin Irritancy Test}

The study was performed after the approval of the Institutional Animal Ethics Committee for using the rabbit. A region of one square $\mathrm{cm}$ was shaved and marked on the thigh surface, and the prepared cream was applied to the predetermined region. Symptoms like irritation, redness, erythema, and edema were checked for a time period up to 24 hours and reported.

\subsubsection{Determination of Type of Emulsion (Dilution Test)}

In the dilution test, a prepared emulsion cream was diluted with oil and water. The cream was diluted first with water, and if the formulation cream remains stable, it is regarded as o/w emulsion cream. Next, the cream was diluted with oil; if the emulsion breaks, it is w/o emulsion as oil is not miscible with water. The prepared polyherbal vanishing cream was found to be $\mathrm{o} / \mathrm{w}$ type.

\subsubsection{Stability Studies}

The stability studies for a drug component are performed according to the ICH guidelines. Stability testing of a drug molecule starts with the drug discovery and finishes with the death of the compound. The cream was filled in a tube and placed in the humidity chamber maintained at $40 \pm 2{ }^{\circ} \mathrm{C}$ and $75 \pm 5 \% \mathrm{RH}$ for one month. At the end of the study, samples were investigated for the physical properties, $\mathrm{pH}$ and viscosity (Kuchekar \& Bhise, 2012). The observations are shown in Table 4.

\section{RESULTS}

The prepared polyherbal vanishing cream was evaluated for the different parameters and the results are tabulated in Table 3.

\subsection{Presence of Unwanted Substances}

The prepared polyherbal vanishing cream produces uniform distribution, which was established by visual detection and touch.

Table 4: Accelerated stability studies

\begin{tabular}{llllll}
\hline Time interval & Homogeneity & Type of smear & Viscosity $(c p)$ & $p H$ & Physical changes \\
\hline $0^{\text {th }}$ Day & +++ & +++ & 1212 & 6.10 & No change in color and odor \\
$5^{\text {th }}$ Day & +++ & +++ & 1217 & 5.9 & No change in color and odor \\
$10^{\text {th }}$ Day & +++ & +++ & 1218 & 5.8 & No change in color and odour \\
$20^{\text {th }}$ Day & +++ & +++ & 1218 & 5.8 & No change in color and odor \\
$30^{\text {th }}$ Day & +++ & +++ & 1218 & 5.8 & No change in color and odor \\
\hline
\end{tabular}

$+=$ average,$\quad++=$ good,$\quad+++=$ excellent 


\subsection{Strength of $\mathrm{pH}$}

The $\mathrm{pH}$ of the prepared polyherbal vanishing cream was found to be in a range of 5.8 to 6.10 , which is superior for every type of skin.

\subsection{Viscosity}

The viscosity of the prepared polyherbal vanishing cream was in the range of $1100-1800 \mathrm{cps}$. This proves that the prepared vanishing cream was easily spreadable by a small amount of shear.

\subsection{Irritancy Test}

The prepared polyherbal vanishing cream was devoid of any symptoms of irritation, redness, inflammation, erythema and oedema as a result of skin irritancy studies. Hence, prepared polyherbal vanishing cream formulation is safe and protected to use for skin.

\section{DISCUSSION AND CONCLUSION}

The present work focuses on the potential of combining various herbal components to get a multipurpose effect on the skin for cosmetic purposes. The uses of cosmetics have been increased in the personal care system, and the bioactive ingredients in it influence the biological functions of skins (Akhtar et al., 2011). The natural herbs used in the preparation of polyherbal vanishing cream was previously reported to have anti-fungal, anti-microbial, anti-inflammatory, skin-soothing activities for which it retards aging signs and pimple formation reduces wrinkles and protects from sunlight (Saraf and Kaur, 2010). The prepared formulation is devoid of any phase separation activity, showed good spreadability and consistency during the entire study period. Various parameters, such as visual appearance, nature, and fragrance of the formulations further elaborated that there was no significant variation during the study period. These studies suggest that the polyherbal composition of extract and base of vanishing cream are stable and safe without side effects due to the presence of many natural compounds.

Further studies are required for verifying the synergistic potential of selected scientifically Polyherbal vanishing cream formulation.

\section{REFERENCES}

1. Akhtar N, Shahiq-uz-zaman, Khan B. A., Haji M., Khan S., Mahmood A., Rasool F., Tariq M. and Akhtar R. (2011).
Evaluation of various functional skin parameters using a topical cream of Calendula officinalis extract. African Journal of Pharmacy and Pharmacology. Vol 5(2): pp. 199-206.

2. Brookfield $\mathrm{DV}-\mathrm{II}^{+}$programmable viscometer operating instructions, Brookfield Engineering laboratories: 1-75.

3. Das K., Dang R., Machale M. U., Ugandar R. E., Lalitha B. R. (2012) Evaluation for safety assessment of formulated vanishing cream containing aqueous Stevia extract for topical application. Indian Journal of Novel Drug Delivery. 4(1): 43-51.

4. Datta H. S. and Paramesh R. (2010). Trends in aging and skin care: Ayurvedic concepts, Journal of Ayurveda and Integrative Medicine. 1(2): 110-113.

5. Dwivedi G. and Dwivedi S. (2007). History of Medicine: Sushruta - the Clinician - Teacher par Excellence. National Informatics Centre.

6. Faisal S. (2019). Global Herbal Medicine Market Growth 2019-2024. Report Ocean.

7. Indian Standard, Specification for Hair Creams. Indian Standard institution, Edition 1, 1978: 11-12.

8. Kuchekar S and Bhise K. (2012). Formulation and development of antipsoritic herbal gel cream. Journal of scientific and industrial research. Vol 71: page no. 279284.

9. Matangi S. P., Mamidi S. A., Gulshan M. D., Raghavamma S. T. V., Nadendla R. R. (2014). Formulation and Evaluation of Anti Aging Poly Herbal Cream Int. J. Pharm. Sci. Rev. Res. 24(2): 133-136.

10. Osborne D. W. (2008). Review of changes in topical drug classification. Pharm. Tech. 32: 66-74.

11. Saraf S., Kaur C. D. (2010). Phytoconstituents as photoprotective novel cosmetic formulations, Pharmacogn. Rev. 4(7): 1-11.

12. Saraf, S., and Saraf, S. (2019). Cosmetics: a practical manual. Third Edition. Pharma Med Press. pp 1-150.

13. Steven D. (2015). Complementary and Alternative Medicine. A Review. Penn State Hershey Medical Center, Adams Publications. (Retrived from http:// /pennstatehershey.adam.com/ content.aspx?productid=107)

14. Ugandar R. E. and Deivi K. S. (2013). Formulation and evaluation of natural palm oil based vanishing cream. International Journal of Pharmaceutical Science and Research. Vol 4(9): 3375-3380.

15. What Is Herbal Medicine? Research Paper. Alternative Medicine, Herbalism, Pharmacology, Study Mode.

How to cite this article: Fahad M. U., Kaleem M. U., Ahmed M. A., Samreen S. and Habeeb (2020). Preparation and Evaluation of Polyherbal Vanishing Cream of Ethanolic Extract of Crude Drugs. Int. J. Appl. Pharm. Sci. Res. 4(4): 63-67. doi: https://doi.org/10.21477/ ijapsr.4.4.3

Source of Support: Nil.

Conflict of Support: None declared. 